\title{
ARAUCARIA CLONAL FORESTRY: TYPES OF CUTTINGS AND MOTHER TREE SEX IN FIELD SURVIVAL AND GROWTH
}

Keywords:

Araucaria angustifolia

Growth habit

Volumetric increment

Vegetative propagation

Histórico:

Recebido 24/I I/2015

Aceito 04/01/2016

Palavras chave:

Araucaria angustifolia

Hábito de crescimento

Incremento volumétrico

Propagação vegetativa

Correspondência: ivar.wendling@embrapa.br
ABSTRACT: Araucaria angustifolia (Bert.) O Kuntze (Paraná pine or Araucaria) is a potential forestry native species for Brazilian silviculture. However, a number of challenges and technical restraints persist, hindering its silvicultural expansion, among which are the lack of cloning technologies of superior genetic materials and their assessment under field conditions. Thus, we evaluated the potential use of araucaria plants derived from cuttings and seeds for timber production, by assessing field survival, growth and strobilus production using cuttings from male and female plants, collected from different positions, compared with those produced by sexual reproduction. Clones of male and female trees from different types of cuttings and seedlings were planted in $3 \times 3 \mathrm{~m}$ spacing. The experiment was conducted in a completely randomized design of one tree plot with three treatments. Female clones and apical cuttings showed higher growth in diameter at breast height $(6.4 \mathrm{~cm})$ and total height $(3.6 \mathrm{~m}) 74$ months after planting, followed by seedlings and other clones, with similar results. We conclude that cuttings technique is potential for araucaria propagation for wood production purposes, and it is favored by the use of apical cuttings from female mother trees.

\section{SILVICULTURA CLONAL DE ARAUCÁRIA: TIPO DE ESTACA E SEXO DA PLANTA MATRIZ NA SOBREVIVÊNCIA E CRESCIMENTO EM CAMPO}

RESUMO: Araucaria angustifolia é uma espécie nativa potencial para a silvicultura brasileira. No entanto, uma série de desafios e limitações técnicas ainda persistem, dificultando sua expansão silvicultural, dentre os quais se destaca a falta de tecnologias de clonagem de materiais genéticos superiores, bem como sua avaliação em condições de campo. Assim, objetivou-se avaliar a potencialidade da utilização de mudas de araucária oriundas de estaquia e de sementes para produção madeireira, por meio da avaliação da sobrevivência e crescimento a campo. Clones provenientes de matrizes masculinas e femininas, de diferentes tipos de estacas e mudas de sementes foram plantadas em espaçamento $3 \times 3 \mathrm{~m}$. O experimento foi conduzido em delineamento inteiramente casualizado, com três tratamentos e parcelas de uma planta (one tree plot). Clones do sexo feminino e de estacas contendo o ápice apresentaram maior crescimento em diâmetro à altura do peito $(6,4 \mathrm{~cm})$ e altura total $(3,6 \mathrm{~m})$ aos 74 meses após o plantio, seguidas das de sementes e demais clones, com resultados similares. Conclui-se que a estaquia é uma técnica potencial de produção de mudas de araucária para fins madeireiros e é favorecida pela utilização de estacas proveniente de matrizes femininas e com ápice. 


\section{INTRODUCTION}

Clonal forestry has generated significant gains for wood production in Brazil and in the world (MARTINS et al., 20I I; ROSADO et al., 20I2). Formation of forests with high uniformity, good adaptation to different environments and greater productivity are some of the benefits that can be obtained (BELTRAME et al., 20I2).

The theory of evolution in plants suggests that males and females may have developed resource allocation strategies to maximize the reproductive success. A consequence of these adaptations could be the appearance of a phenotypic, biochemical, and ecological dimorphism, resulted from the resource allocation specified for each sex, creating a state of great application depending on the specific needs of each sex (ROBINSON et al., 20I4). Height and diameter have been the phenotypic characteristics most used as indicators to analyze these changes related to sex, considering that the vegetative vigor is the result of a larger adaptive capacity (DUDLEY, 2006; PETZOLD et al., 20 I2).

Araucaria angustifolia (Bertol.) Kuntze (Araucariaceae), popularly known as araucaria or Brazilian pine, occurs naturally in the South of Brazil, especially in the Eastern and Central part of Brazilian's plateau (CARVALHO, 2003). Its wood has very attractive features, being recommended both for civil engineering and pulp and paper production (AQUINO, 2005; CARVALHO, 2003; DELUCIS et al., 20I3). It has been characterized as one of the native species with the largest amount of research in the area of improvement and conservation of genetic resources (AQUINO, 2005). However, the results obtained so far regarding its qualification for silvicultural purposes are obsolete, especially due to the difficulties related to asexual propagation of the species (PIRES et al., 20I3; WENDLING; BRONDANI, 20I5; WENDLING et al., 2009).

Commonly produced from seeds, araucaria presents fairly simple seedlings production, eliminating the use of technologies needed for vegetative propagation. However, the difficulty of storing viable seeds, their recalcitrant characteristic, the production of seedlings with different characteristics from the mother plant (quality of wood, time of production, seed quality and sex), its long period and its seasonality have constituted drawbacks to sexual reproduction (MOREIRA-SOUZA; CARDOSO, 2003).

The use of cuttings for Araucaria angustifolia propagation presents itself as an alternative for overcoming these deficiencies, generating quality, uniformity and, above all, enabling plants production during the whole year (GRIFFIN, 20I4; REIS et al., $20 \mathrm{II}$ ). However, reports to assess the behavior of plants produced by cuttings in the field are inexistent and necessary, being available only assessments populations from seminal origin (CHASSOT et al., 20I I; HESS et al., 2009; SCHNEIDER et al., 1992).

Thus, we evaluated the potential use of araucaria plants derived from cuttings and seeds for timber production, by assessing field survival, growth and strobilus production using cuttings from male and female plants, collected from different positions, compared with those produced by sexual reproduction.

\section{MATERIAL AND METHODS}

This experiment was conducted from May/2008 to June/2014 at the Experimental Station of Embrapa

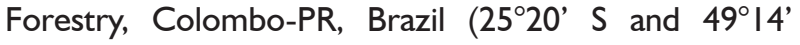
W, $950 \mathrm{~m})$. According to the Köppen-Geiger climate classification, the region's climate is temperate of the $\mathrm{Cfb}$ type, with temperature of the coldest month between -3 and $18^{\circ} \mathrm{C}$, always humid, with rainfall well distributed throughout the year and average temperature of the hottest month below $22^{\circ} \mathrm{C}$ (Figure I).

The local soil is Humic Cambisol Dystrophic saprolite, medium-textured (open-clay), with low fertility (Table I).

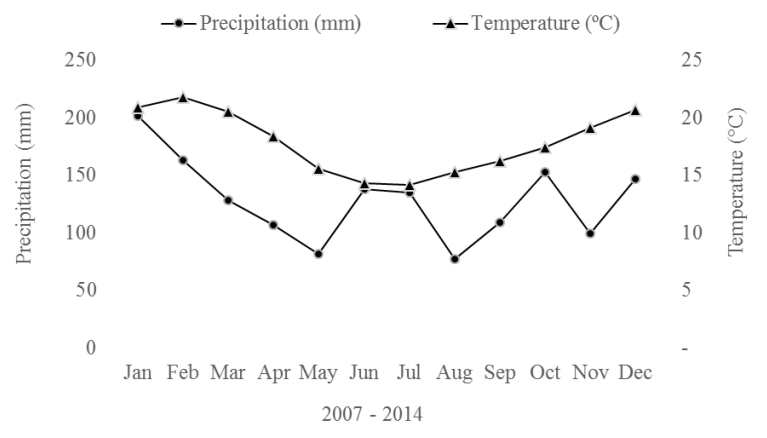

FIGURE 1 Means of maximum and minimum temperatures and rainfall for the region of Colombo-PR, Brazil between January/2014 and June/2014 (SIMEPAR/PR).

FIGURA 1 Médias das temperaturas máximas e mínimas e da precipitação acumulada para região de ColomboPR, entre os meses de janeiro/2007 a junho/2014 (SIMEPAR/PR).

Cuttings had their production started in July/2007, with shoots obtained from 26-year-old trees' basal epicormic sprouts (cut in July/2006). Trees were stablished in a provenances and progenies trial of Embrapa 
TABLE 1 Soil's clay content and chemical properties of the trial area from 0 to $30 \mathrm{~cm}$ and 50 to $80 \mathrm{~cm}$ of depth.

TABELA 1 Teor de argila e propriedades químicas do solo da área experimental de 0 a $30 \mathrm{~cm}$ e 50 a $80 \mathrm{~cm}$ de profundidade.

\begin{tabular}{cccccccccccccc}
\hline $\begin{array}{c}\text { Depth } \\
(\mathrm{cm})\end{array}$ & $\mathrm{pH}$ & $\mathrm{Ca}$ & $\begin{array}{c}\mathrm{Mg} \\
\left(\mathrm{cmolc} \cdot \mathrm{dm}^{-3}\right)\end{array}$ & $\begin{array}{c}\mathrm{Al} \\
\left(\mathrm{cmolc} \cdot \mathrm{dm}^{-3}\right)\end{array}$ & $\begin{array}{c}\mathrm{H}+\mathrm{Al} \\
\left(\mathrm{cmolc} \cdot \mathrm{dm}^{-3}\right)\end{array}$ & $\begin{array}{c}\mathrm{T} \\
\left(\mathrm{cmolc} \cdot \mathrm{dm}^{-3}\right)\end{array}$ & $\begin{array}{c}\mathrm{V} \\
(\%)\end{array}$ & $\begin{array}{c}\mathrm{m} \\
(\%)\end{array}$ & $\begin{array}{c}\mathrm{C} \\
\left(\mathrm{g} \cdot \mathrm{dm}^{-3}\right)\end{array}$ & $\begin{array}{c}\mathrm{P} \\
\left(\mathrm{mg}^{2} \cdot \mathrm{dm}^{-3}\right)\left(\mathrm{mg}^{2} \cdot \mathrm{dm}^{-3}\right)\end{array}$ & $\begin{array}{c}\mathrm{Clay} \\
\%\end{array}$ \\
\hline $0-30$ & 4.30 & 2.60 & 1.20 & 1.70 & 10.50 & 14.37 & 27 & 31 & 27.6 & 5.00 & 0.07 & 25 \\
$50-80$ & 4.30 & 0.30 & 0.20 & 3.40 & 8.40 & 8.94 & 6 & 86 & 3.1 & 1.5 & 0.04 & 32.5 \\
\hline
\end{tabular}

Extractors: Mehlich-1 ( $\mathrm{P}$ and $\mathrm{K})$; and $\mathrm{KCl}(\mathrm{Ca}, \mathrm{Mg}$ and $\mathrm{Al})$.

Extratores: Mehlich-1 (P e K); e KCl (Ca, Mg e Al).

Forestry, Colombo-PR, Brazil. From the orthotropic sprouts of male and female plants we prepared two kinds of cuttings, the first from the apical region of the branches (apical cuttings) and the second from the intermediate area, with straight cut above the last bud (intermediate cuttings) (WENDLING; BRONDANI, 20I5).

Cuttings were prepared $2 \pm 2 \mathrm{~cm}$ long and diameter between 5 and $10 \mathrm{~mm}$, applying a bevel cut at the base and removal of $1 / 3$ of the needles in the basal region, aiming to facilitate the planting. They were planted in polypropylene tubes with capacity of 170 $\mathrm{cm}^{3}$, filled with vermiculite of medium granulometry and carbonized rice husk (I:I, v/v).

The tubes were put in a climatized greenhouse for 120 days with intermittent fogging (temperature of $25^{\circ} \mathrm{C} \pm 5^{\circ} \mathrm{C}$ and relative humidity higher than $80 \%$ ). Later, the cuttings underwent the process of acclimation in shade house (shading of $50 \%$ ) during 30 days and the rustication in full sun area for over 30 days.

Seedlings were produced from seeds derived from the city of Faxinal do Céu-PR (240's and $\left.51^{\circ} 19^{\circ} \mathrm{O}\right)$. They were also produced in small tubes with a $170 \mathrm{~cm}^{3}$ of capacity, and went through the rustification process where hardening fertilizer was applied (4 g.L.-1 de ammonium sulfate, $10 \mathrm{~g} \cdot \mathrm{L}^{-1}$ of simple superphosphate, 4 $\mathrm{g} \cdot \mathrm{L}^{-1}$ of potassium chloride and I $\mathrm{g} \cdot \mathrm{L}^{-1}$ of FTE BR 10) and pre-planting selection for the treatments homogenization.

The field planting was done in May/2008, in circular pits of $75 \mathrm{~cm}$ depth and $25 \mathrm{~cm}$ diameter, carried out with the use of a soil drilling machine coupled with tractor's socket outlet. The spacing was $3 \times 3 \mathrm{~m}$ with a simple border. Fertilizing with $200 \mathrm{~g}$ of 4- I4-8 (N-P $\mathrm{O}_{5}$ $\mathrm{K}_{2} \mathrm{O}$ ) per pit was carried out, being incorporated along with the soil removed from the pits. At the time of planting, cuttings were ten months old, and the seedlings, five months.

Prior to the field planting, a mechanical grubbing was carried out in the total area of the experiment, followed by the control of leaf-cutting ants. The postplanting silvicultural treatments consisted in mechanical grubbing every six months, and control of leaf-cutting ants whenever necessary. In September of 2013 pruning was done, removing $1 / 3$ of the crown area of each plant.

Throughout the experiment we assessed the survival of plants (cuttings and seedlings) 9 months after the field planting, as well as the total height (at 48, 66 and 74 months), diameter at breast height $(\mathrm{DBH})$ and occurrence of male and female reproductive organs in plants at 66 and 74 months. Using the established form factors for clonal and seminal plants under similar edaphoclimatic conditions (Table 2), the volume index per plant and the mean annual increment per hectare at 66 and 74 months were calculated.

In the experimental design, randomized blocks of one tree plot were used, consisting of four treatments, varing according to the sex of the mother plant and the origin of the propagating material in the production of cuttings and seedlings as witnesses. The treatments corresponded to: I - cuttings from intermediate area of orthotropic shoots of female plants (CFI); 2 - cuttings from apical area of orthotropic shoots of female plants (CFP); 3 - cuttings from apical area of orthotropic shoots of male plants (CMP); 4 - seedlings produced by seeds (S).

TABLE 2 Estimate of the real average volume, cylinder average volume and average form factor of Araucaria angustifolia plants derived from cuttings and seeds per diametric class.

TABELA 2 Estimativa do volume médio real, volume médio do cilindro e fator de forma médio de plantas de Araucaria angustifolia provenientes de estaquia e de sementes por classe diamétrica.

\begin{tabular}{|c|c|c|c|c|c|}
\hline $\begin{array}{c}\text { Propagation } \\
\text { method }\end{array}$ & $\begin{array}{l}\text { Class } \\
\text { Center } \\
(\mathrm{cm})\end{array}$ & $\begin{array}{c}\text { Real } \\
\text { Volume } \\
\left(\mathrm{m}^{3}\right)\end{array}$ & $\begin{array}{c}\text { Cylinder } \\
\text { volume } \\
\left(\mathrm{m}^{3}\right)\end{array}$ & $\begin{array}{c}\text { Average } \\
\text { Form } \\
\text { Factor }\end{array}$ & $\begin{array}{c}\text { Standard } \\
\text { error of } \\
\text { the mean* }\end{array}$ \\
\hline \multirow{3}{*}{ Cuttings } & 7.1 & 0.020 & 0.047 & 0.42 & 0.017 \\
\hline & 7.1 & 0.043 & 0.096 & 0.45 & 0.087 \\
\hline & 4.6 & 0.058 & 0.111 & 0.52 & 0.040 \\
\hline \multirow{3}{*}{ Seedlings } & 3.1 & 0.004 & 0.008 & 0.52 & 0.111 \\
\hline & 3.1 & 0.010 & 0.018 & 0.57 & 0.037 \\
\hline & 5.1 & 0.017 & 0.035 & 0.47 & 0.035 \\
\hline
\end{tabular}

*Standard error of the mean $(n=2)$ ** 
We used 8 to 66 replications per treatment (depending on the material availability) for field planting. For statistical analysis, treatments variances were evaluated for homogeneity using the Bartlett test $(p<0.05)$, and variables with significant differences by the $\mathrm{F}$ test had their means compared by the Tukey test at $5 \%$ of probability.

\section{RESULTS AND DISCUSSION}

Nine months after field planting, all treatments with plants propagated vegetatively (cuttings) had high survival rate, significantly superior compared to those from seeds (76\%, Figure 2 ). The survival rate of cuttings, regardless of plants sex and sprouts origin, indicate a good potential of initial adaptation of those plants to planting conditions (Figure 2).

Several studies focus on the use of production techniques that enable a greater adaptive capacity of plants in field stress conditions (SWORD SAYER et al., 20II; TSAKALDIMI; GANATSAS, 2006). The use of appropriate production and rustication techniques in nurseries has propitiated the formation of plants with these attributes, which reflect on the success of these plantations (GROSSNICKLE, 20I2), as verified for cuttings.

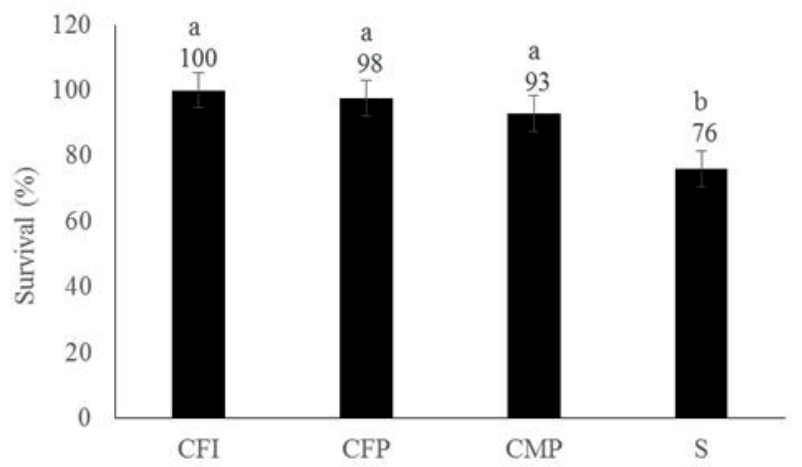

FIGURE 2 Survival of Araucaria angustifolia plants nine months after planting. The bars indicate the standard error of the mean $(n=20)$. In which: $C F I=$ Plants produced by cuttings from intermediate area of female plants' shoots; CFP = Plants produced by cuttings from apical area of female plants shoots; CMP = Plants produced by cuttings from apical area of male plants' shoots and; $\mathrm{S}=$ Plants produced by seeds. Means followed by the same letter do not differ among themselves by the Tukey test at $5 \%$ probability.

FIGURA 2 Sobrevivência de plantas de Araucaria angustifolia aos nove meses após o plantio. As barras indicam o erro padrão da média $(n=20)$. Onde: $C F I=$ Mudas produzidas com estacas da parte intermediária dos ramos de plantas femininas; CFP = Mudas produzidas com estacas da parte apical dos ramos de plantas femininas; CMP = Mudas produzidas com estacas da parte apical dos ramos de plantas masculinas e; $\mathbf{S}=$ Mudas produzidas por sementes. Médias seguidas por mesma letra não diferem entre si pelo teste de Tukey a $5 \%$ de probabilidade.
It is necessary to highlight that plants survival presents a greater dependence on the availability of water than nutrients in the early stage of adaptation post-planting. In general, the water stress during this period, regardless of the availability of nutrients or light, determines the plantations' success (ANDIVIA et al., 20I2; THIFFAULT et al., 20I3).

It is common in some species for vegetative propagation to assign different characteristics, such a more fasciculated root system with more volume of thin roots in the early stage of its development, transferring to these plants greater adaptive capacity in terms of water and nutritional deficit (GONÇALVES; MELLO, 2005; SANTIN et al., 20I5). We did not rule out the hypothesis that araucaria's cuttings have developed a more efficient root system regarding water absorption, favoring a better survival rate of plants in the field.

Height growth of plants remained constant up to 74 months without evidence of growth peaks throughout the trial period, regardless of the material assessed (Figure 3 - left). The average cumulative growth in height of apical female clones (CFP) ranged from $0.45 \mathrm{~m} \cdot \mathrm{year}^{-1}$ at 48 months to $0.59 \mathrm{~m} \cdot$ year $^{-1}$ at 74 months, surpassing the average cumulative growth of other clonal origins and also of plants derived from seeds $\left(0.51\right.$ m.year $\left.{ }^{-1}\right)$ at 74 months.

Characterized by a slow initial development, araucaria can present, in some cases, average accumulated growth in height of up to $1.0 \mathrm{~m} \cdot$ year $^{-1}$ at 36 months (CARVALHO, 2003). Slow growth is sustained by the natural conditions of species development, demanding when it comes to soil conditions, especially regarding depth (PUCHALSKI et al., 2006) and nutrient availability (CARVALHO, 2003; MOREIRA-SOUZA; CARDOSO, 2002; SCHNEIDER et al., 1992).

In a study with the species, Schneider et al. (1992) verified dominant height at 70 months of 2.7 and $5.5 \mathrm{~m}$ for the worst and best site in the same region, confirming the significant influence of soil properties on plantation efficiency. Thus, the low fertility of the local soil, mainly due to the low availability of $\mathrm{P}$ and $\mathrm{K}$ (Table I), may have contributed to a growth in height less than the one recorded for the same species with similar ages.

Soil inversion limited to the area of the pit may not have favored the mixture between the surface (organic) and deeper layers, easily reached by subsoiling or scarification and referenced by the increased availability of water to the plants in initial stage of development, facilitating the root development in the early years (THIFFAULT et al., 20I3). Furthermore, in higher quality 
sites, plants tend to grow and compete with each other for nutrients, while in lower quality sites the priority is survival (MARTINS et al., 20I I).

Similar to total height, apical female clones (CFP) showed highest values for diameter at breast height $(\mathrm{DBH})$ at $66(4.0 \mathrm{~cm})$ and 74 months $(6.4 \mathrm{~cm})$ of age (Figure 3 - right). Regarding araucaria plants aged between 40 and 60 years, Zanon et al. (2009) verified the average growth in diameter of $0.24 \mathrm{~cm} \cdot y^{-1}$, proving to be lower than those verified for plants derived from mother plants' cuttings (CFP) with apical branches (I.4

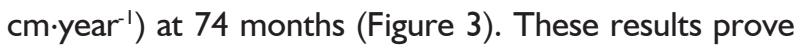
the theory of high vigor associated with the juvenile phase of this species (MACHADO et al., 20I4). In addition, they show what should be a trend as the population evolves, even under limiting edaphic conditions, highlighting the positive effect of using clones, regardless of sex and origin of cuttings for the species' silviculture.

The cumulative volume index per plant (Figure 4 - left) and the mean annual increment (MAl) per hectare (Figure 4 - right) were higher in apical female clones (CFP) in both evaluations. The evolution of both volume index and the mean annual increment at 74 months is evident. In both cases, the highest values for CFP were around 2.I and I.6 times higher compared to the values verified for $\mathrm{CFI}$ and seedlings, respectively at 74 months.

Comparing the individual volume and the MAI in both periods of evaluation (66 and 74 months), it is clear that the population is in a linear positive growth (Figure 4 ). The increase in wood productivity verified over the last eight months (from 66 to 74 months), was superior to the MAI, regardless of treatment. These results suggest a common effect in tree species during their first years of life, whose growth is very dependent of the apical meristem (MENCUCCINI et al., 2007). In addition, there are evidences that araucaria reaches its best development after 30 years of age (AQUINO, 2005).

The values of MAl verified for araucaria in this study are close to those found for some coniferous species. In populations of Pinus taeda with $6.25 \mathrm{~m}^{2}$. plant $^{-1}$, mean annual increment at 72 months was ranging between 5.3 and $26.6 \mathrm{~m}^{3} \cdot \mathrm{ha}^{-1}$.year-1 (SHIMIZU; HIGA, 198I). However, in plantations of different spacings from the same species, Lima et al. (20l3) verified a range of mean annual increment of $7.5 \mathrm{~m}^{3} \cdot$ ha $^{-1} \cdot$ year $^{-1}\left(7.5 \mathrm{~m}^{2}\right)$ and $24.8 \mathrm{~m}^{3} \cdot \mathrm{ha}^{-1}$. year ${ }^{-1}\left(4.0 \mathrm{~m}^{2}\right)$. In this context, araucaria, combined with high-quality wood (CARVALHO, 2003), presents itself as a good alternative for silvicultural purposes, especially with the use of high-yield genotypes. Despite the initial development below expectations, probably related to edaphic conditions (Table I), this tends to evolve with the best plants adaptating to the environment, or even with the use of areas with better fertility conditions.

Regarding the emission of male and female strobilus, up to 74 months after planting, its emission
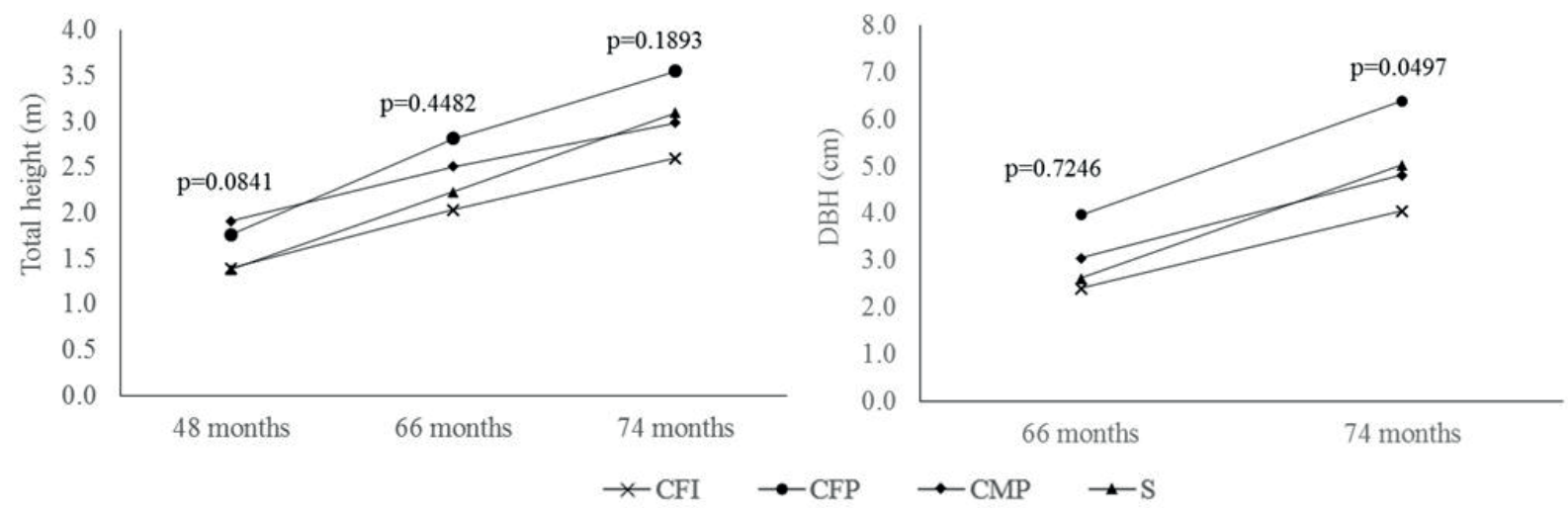

FIGURE 3 Mean total height at 48, 66 and 74 months after planting (left) and diameter at breast height (DBH) at 66 and 74 months after planting (right) by to propagation method and origin of the plants used in the plantation of Araucaria angustifolia. In which: CFI = Plants produced by cuttings from intermediate area of female plants' shoots; CFP = Plants produced with cuttings from apical area of female plants' shoots; CMP = Plants produced with cuttings from apical area of male plants' shoots and; $\mathrm{S}=$ Plants produced by seeds.

FIGURA 3 Altura total média aos 48, 66 e 74 meses após o plantio (esquerda) e diâmetro à altura do peito (DAP) aos 66 e 74 meses após o plantio (direita) em função do método de propagação e origem das mudas utilizadas no plantio de Araucaria angustifolia. Onde: $\mathrm{CFI}=$ Mudas produzidas com estacas da parte intermediária dos ramos de plantas femininas; CFP = Mudas produzidas com estacas da parte apical dos ramos de plantas femininas; CMP = Mudas produzidas com estacas da parte apical dos ramos de plantas masculinas e; $S=$ Mudas produzidas por sementes. 


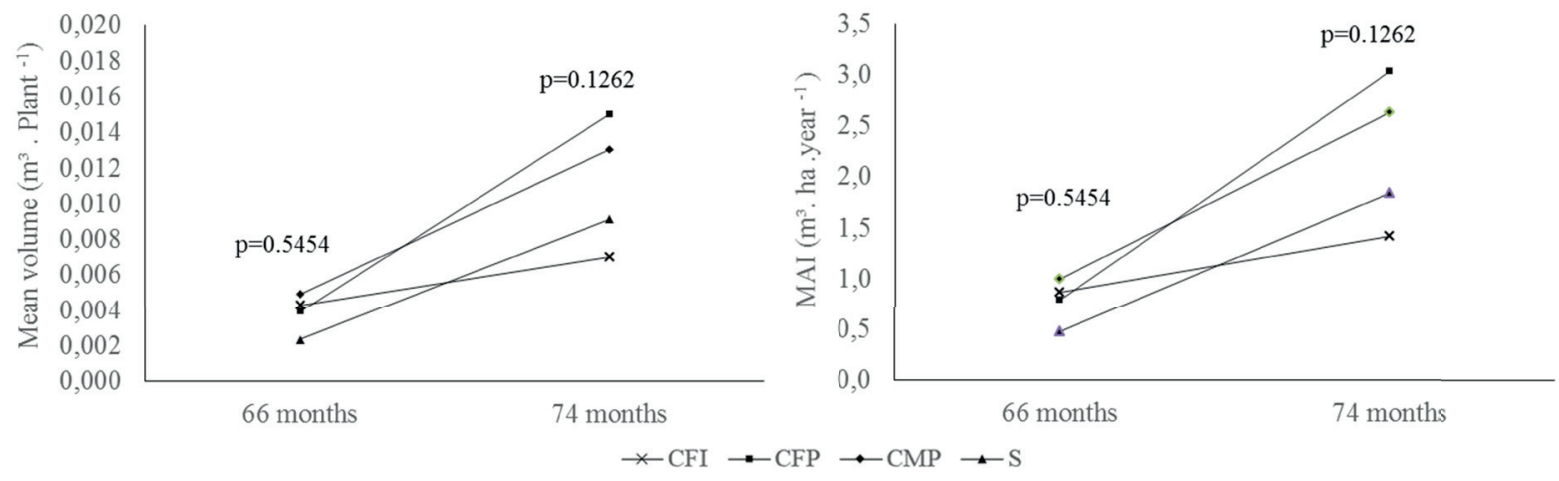

FIGURE 4 Cumulative mean volume (left) and mean annual increment (MAI) (right) at 66 and 74 months after plantation due to propagation method and origin of plants used in the plantation of Araucaria angustifolia. In which: CFI = Plants produced by cuttings from intermediate area of female plants' shoots; CFP = Plants produced with cuttings from apical area of female plants' shoots; CMP = Plants produced with cuttings from apical area of male plants' shoots and; $S=$ Plants produced by seeds.

FIGURA 4 Volume médio acumulado (esquerda) e incremento médio anual (IMA) (direita) aos 66 e 74 meses após o plantio em função do método de propagação e origem das mudas utilizadas no plantio de Araucaria angustifolia. Onde: $\mathrm{CFI}=\mathrm{Mudas}$ produzidas com estacas da parte intermediária dos ramos de plantas femininas; CFP = Mudas produzidas com estacas da parte apical dos ramos de plantas femininas; CMP = Mudas produzidas com estacas da parte apical dos ramos de plantas masculinas $\mathrm{e} ; \mathrm{S}=$ Mudas produzidas por sementes.

was not observed, regardless of sex and origin of the cuttings. Emission of reproductive organs is an important marker of maturation in plant species, indicating the loss of juvenility (WENDLING et al., 2014).

In Araucaria angustifolia, emission of strobilus and subsequent fruiting starts between 10 and 15 years of age in isolated trees and from 20 years of age in homogeneous plantations (CARVALHO, 2003). In arboretum established in Kenya, the seed production occurred from 13 to I5 years of age (NTIMA, 1968). These results demonstrate that the plants production method was efficient and kept vigor associated with the juvenile phase of this species.

\section{CONCLUSIONS}

Vegetative propagation is a potential technique for araucaria plants production for wood purposes. The use of female plants' apical cuttings is recommended, due to the observed best growth performance in the field, facilitating the process of plants production.

\section{ACKNOWLEDGMENTS}

We would like to thank SIMEPAR for making available the data regarding temperature and humidity for the city of Colombo, PR, Brazil And to CNPq for financing part of the research.

\section{REFERENCES}

ANDIVIA, E.; MARQUEZ-GARCIA, B.; VAZQUEZ-PIQUE, J.; CORDOBA, F.; FERNANDEZ, M. Autumn fertilization with nitrogen improves nutritional status, cold hardiness and oxidative stress response of Holm oak (Quercus ilex ssp. ballota (Desf.) Samp.) nursery seedlings. Trees, v. 26, p. $311-320,2012$.

AQUINO, F. M. Cultivo da Araucaria angustifolia: viabilidade econômico-financeira-financeira e alternativas de incentivo. Florianópolis: Banco Regional de Desenvolvimento do Extremo Sul, 2005. 53 p.

BELTRAME, R.; BISOGNIN, D. A.; MATTOS, B. D.; CARGNELUTTI FILHO, A.; HASELEIN, C. R.; GATTO, D. A.; SANTOS, G. A. Desempenho silvicultural e seleção precoce de clones de híbridos de eucalipto. Pesquisa Agropecuária Brasileira, Brasília, v. 47, n. 6, p. 791-796, jun. 2012.

CARVALHO, P. E. R. Espécies arbóreas brasileiras. Brasília: EMBRAPA Informação Tecnológica; Colombo: EMBRAPA Florestas, 2003. 1039 p.

CHASSOT, T.; FLEIG, F. D.; FINGER, C. A. G.; LONGHI, S. J. Modelos de crescimento em diâmetro de árvores individuais de Araucaria angustifolia (Bertol.) Kuntze na Floresta Ombrófila Mista. Ciência Florestal, Santa Maria, v. 21, p. $303-313,201$ I.

DELUCIS, R. A.; GATTO, D. A.; STANGERLIN, D. M.; BELTRAME, R.; TREVISAN, R. Qualificação da madeira de três espécies de coníferas oriundas de reflorestamentos jovens. Scientia Forestalis, v. 4I, n. I00, p. 477-484, 2013. 
DUDLEY, L. S. Ecological correlates of secondary sexual dimorphism in Salix glauca (Salicaceae). American Journal of Botany, v. 93, p. I775-I 783, 2006.

GONÇALVES, J. L. M.; MELLO, S. L. M. O sistema radicular das árvores. In: GONÇALVES, J. L. M.; BENEDETTI, V. (Ed.). Nutrição e fertilização florestal. Piracicaba: IPEF, 2005. p. 219-267.

GRIFFIN, A. R. Clones or improved seedlings of Eucalyptus?: not a simple choice. International Forestry Review, v. I6, n. 2, p. 216-224, 2014.

GROSSNICKLE, S. C. Why seedlings survive: influence of plant attributes. New Forests, v. 43, n. 5/6, p. 7II-738, 2012.

HESS, A. F.; SCHNEIDER, P. R.; FINGER, C. A. G. Crescimento em diâmetro de Araucaria angustifolia (Bertol.) Kuntze em função da idade, em três regiões do Rio Grande do Sul. Ciência Florestal, Santa Maria, v. 19, n. I, p. 7-22, 2009.

LIMA, R.; INOUE, M. T.; FIGUEIREDO FILHO, A.; ARAUJO, A. J.; MACHADO, A. S. Efeito do espaçamento no desenvolvimento volumétrico de Pinus taeda L. Floresta e Ambiente, v. 20, n. 2, p. 223-230, 2013.

MACHADO, A. S.; ZAMIN, N. T.; NASCIMENTO, R. G. M.; SANTOS, A. A. P. Efeito de variáveis climáticas no crescimento mensal de Pinus taeda e Araucaria angustifolia em fase juvenil. Floresta e Ambiente, v. 21 , n. 2, p. I70I8I, $20 \mid 4$.

MARTINS, F. B.; SOARES, C. P. B.; LEITE, H. G.; SOUZA, A. L.; CASTRO, R. V. O. Índices de competição em árvores individuais de eucalipto. Pesquisa Agropecuária Brasileira, Brasília, v. 46, p. 1089-1098, 201 I.

MENCUCCINI, M.; MARTÍNEZ-VILALTA, J.; HAMID, H. A.; KORAKAKI, E.; VANDERKLEIN, D. Evidence for age and size mediated controls of tree growth from grafting studies. Tree Physiology, v. 27, p. 463-473, 2007.

MOREIRA-SOUZA, M.; CARDOSO, E. J. B. N. Dependência micorrízica de Araucaria angustifolia (Bert.) O. Ktze. sob doses de fósforo. Revista Brasileira de Ciência do Solo, Viçosa, v. 26, p. 905-912, 2002.

MOREIRA-SOUZA, M.; CARDOSO, E. J. B. N. Practical method for germination of Araucaria angustifolia (Bert.) $\mathrm{O}$. Ktze. seeds. Scientia Agricola, Piracicaba, v. 60, n. 2, p. 389391, 2003.

NTIMA, O. O. The Araucárias. Oxford: Commonwealth Forestry Institute, 1968. 139 p. (Fast Growing Timber Tees of the Lowland Tropics, 3).

PETZOLD, A.; PFEIFFER, T.; JANSEN, F.; EUSEMANN, P.; SCHNITTLER, M. Sex ratios and clonal growth in dioecious Populus euphratica Oliv., Xinjiang Prov., Western China. Trees, v. 27, p. 729-744, 2012.
PIRES, P. P.; WENDLING, I.; BRONDANI, G. Ácido indol butírico e ortotropismo na miniestaquia de Araucaria angustifolia. Revista Árvore, Viçosa, v. 37, p. 393-399, 2013.

PUCHALSKI, A.; MANTOVANI, M.; REIS, M. S. Variação em populações naturais de Araucaria angustifolia (Bert.) $\mathrm{O}$. Kuntze. associada a condições edafo-climáticas. Scientia Forestalis, v. 70, p. I37-| 48, 2006.

REIS, C. A. F.; GONCALVES, F. M. A.; ROSSE, L. N.; COSTA, R. R. G. F.; RAMALHO, M. A. P. Correspondence between performance of Eucalyptus spp. trees selected from family and clonal tests. Genetics and Molecular Research, v. 10, p. II72-II79, 2011.

ROBINSON, K. M.; DELHOMME, N.; MHLER, N.; SCHIFFTHALER, B.; NSKOG, J.; ALBRECTSEN, B. R.; STREET, N. R. Populus tremula (European aspen) shows no evidence of sexual dimorphism. BMC Plant Biology, v. 14, p. I-14, 2014.

ROSADO, A. M.; ROSADO, T. B.; ALVES, A. A.; LAVIOLA, B. G.; BHERING, L. L. Seleção simultânea de clones de eucalipto de acordo com produtividade, estabilidade e adaptabilidade. Pesquisa Agropecuária Brasileira, Brasília, v. 47, n. 7, p. 964-97I, jul. 2012.

SANTIN, D.; WENDLING, I.; BENEDETTI, E. L.; MORANDI, D.; DOMINGOS, D. M. Sobrevivência, crescimento e produtividade de plantas de erva-mate produzidas por miniestacas juvenis e por sementes. Ciência Florestal, Santa Maria, v. 25, n. 3, p. 57I-579, 2015.

SCHNEIDER, P. R.; FINGUER, A. C. G.; HOPPE, J. M. Produção da Araucaria angustifolia (Bert.) O. Ktze. na região da Planalto Médio do estado do Rio Grande do Sul. Ciência Florestal, Santa Maria, v. 2, n. I, p. 99-I I8, 1992.

SHIMIZU, J. Y.; HIGA, A. R. Variação racial do Pinus taeda L. no Sul do Brasil até o sexto ano de idade. Boletim de Pesquisa Florestal, v. 2, p. I-25, 198I.

SWORD SAYER, M. A.; SUNG, S. J.; HAYWOOD, J. D. Longleaf pine root system development and seedling quality in response to copper root pruning and cavity size. Southern Journal of Applied Forestry, v. 35, p. 5-II, 20II.

THIFFAULT, N.; CHALIFOUR, D.; BELANGER, L. Enrichment planting of Picea glauca in boreal mixedwoods: can localized site preparation enhance early seedling survival and growth? New Forests, v. 44, p. 533-546, 2013.

TSAKALDIMI, M. N.; GANATSAS, P. P. Effects of chemical pruning on stem growth, root morphology and field performance on the Mediterranean pine Pinus halepensis Mill. Scientia Horticulturae, v. I09, p. I83-189, 2006.

WENDLING, I.; BRONDANI, G. Vegetative rescue and cuttings propagation of Araucaria angustifolia. Revista Árvore, Viçosa, v. 39, n. I, p. 93-104, 2015. 
WENDLING, I.; DUTRA, L. F; HOFFMANN, H. A.; BETTIO, G.; HANSEL, F. Indução de brotações epicórmicas ortotrópicas para a propagação vegetativa de árvores adultas de Araucaria angustifolia. Agronomía Costarricense, v. 33, n. 2, p. 309-319, 2009.

WENDLING, I.; TRUEMAN, S.; XAVIER, A. Maturation and related aspects in clonal forestry-part II: reinvigoration, rejuvenation and juvenility maintenance. New Forests, v. I, p. I-I4, 20 I4.
WENDLING, I.; BRONDANI, G. Vegetative rescue and cuttings propagation of Araucaria angustifolia. Revista Árvore, Viçosa, v. 39, n. I, p. 93-104, 2015.

ZANON, M. L. B.; FINGER, C. A. G.; SCHNEIDER, P. R. Proporção da dióicia e distribuição diamétrica de árvores masculinas e femininas de Araucaria angustifolia (Bert.) Kuntze. em povoamentos implantados. Ciência Florestal, Santa Maria, v. 19, p. 425-431, 2009. 